Dept. of Animal Medicine, Clinical Laboratory Diagnosis Fac. of Vet. Med., Assiut University.

\title{
RELATIONSHIP BETWEEN ANTIOXIDANTS AND NEMATODE PARASITIC INFESTATION OF DROMEDARY CAMELS (CAMELUS DROMEDARIES) IN EGYPT
}

(With One Table and One Figure)

By

\section{M.R. ABD ELLAH1; GHADA A. ABOU EL-ELLA and A. ABDEL-RADY*}

* Dept. of Animal Medicine, Infectious Diseases, Fac. of Vet. Med., Assiut University.

(Received at 24/5/2008)

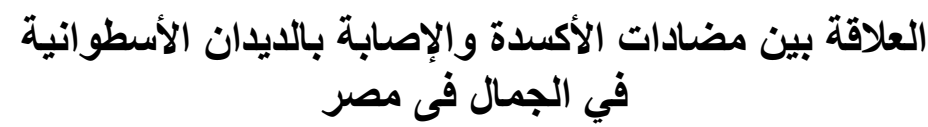

محمولد رشلى عبل الللاه ، غادة /حمد ابوالعلا ، /حمد عبل الراضحى

استهدفت هذه الدر اسة معرفة نوع ودرجة الإصابة بالديدان التي تصيب الجمال المستوردة من

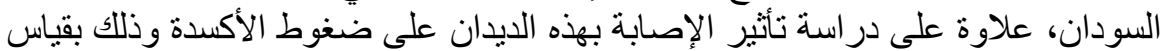
مستوى بعض مضادات الأكسدة المتمثلة في حامض الأسكور بيك وفيك وفيتامين هـ.

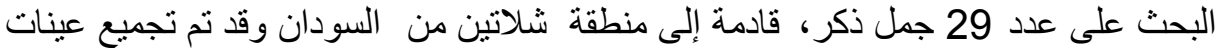

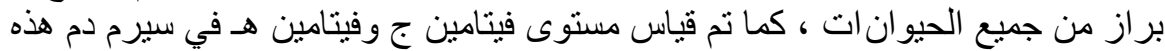

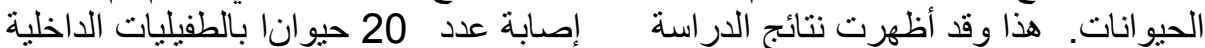

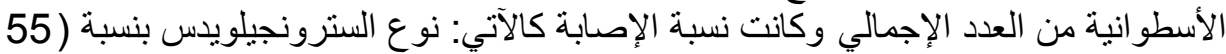
\%)، نوع التريكيوريس بنسبة إصابة ( 25\%)، نوع التريكوسنرونجيلس ( 20\%). أظهرت النتائج وجود نقص معنوي في مستوى حامض الأسكوربيك وذللك في جميع الحيوانات

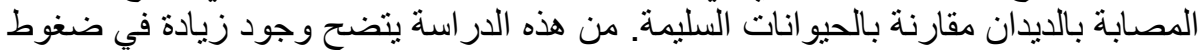

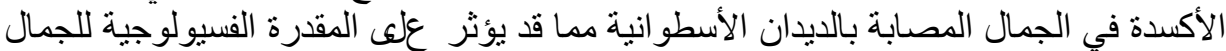
على التكيف مع الظروف الغذائية الصعبة أثناء السفر لمسافات طويلة مما قد يؤثر على على إنتاجية ومقدرة هذه الحيوانات على العمل تحت هذه الظعلى الظروف.

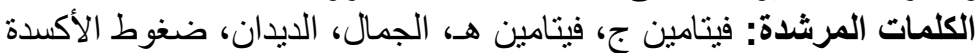

\section{SUMMARY}

The goal of the present study was to determine the type and burden of parasitic infestation in camels imported from Sudan to investigate the effect of enteric parasitism on the oxidative status of affected camels 
manifested by the changes of the levels of some chain breaking antioxidants. In the present study, a total of 29 camels (5-9 years) from a herd of imported camels were subjected to clinical examination in Shalateen area. Fecal samples were collected from all examined camels for evaluation of their parasitic status. Blood serum samples were collected from all animals and were used for evaluation of serum levels of vitamin $\mathrm{C}$ (L-ascorbic acid) and vitamin $\mathrm{E}$ ( $\alpha$ - tocopherol). The results of the study showed that out of the examined 29 camels, 20 camels $(69 \%)$ were found infested with nematode parasites, some of which showed variable non-specific clinical manifestations. The study revealed the presence of three types of nematodes; Strongyloid, Trichuris and Trichostrongylus species from 55\%, 25\% and 20\% from infested camels, respectively. The results also revealed the presence of significant reduction in the serum level of ascorbic acid in all parasitic infested camels as compared with healthy ones. On the other hand, none of the parasitic infested camels showed insignificant change in the serum level of vitamin E. In conclusion, parasitic infestation of camels may interfere with the oxidative status and increase the oxidative stress of their bodies with the subsequent adverse effect on camel health and ability to endure harsh environment.

Key Words: Vitamin C, Vitamin E, Camels, Parasitic infestation, oxidative stress

\section{INTRODUCTION}

Parasitic infestation among farm animals constitutes a major hazard to livestock production. Gastrointestinal nematodes are chronic pervasive infections that contribute world wide to morbidity and mortality in livestock. In camels, parasitic infestation is the third most important production constraint (Rutagwende, 1985 and Dia, 2006). In General, parasitic infestation interferes with nutrient availability to the host through both reduction of feed intake and/or reduction of efficient absorption of required nutrients. The gastrointestinal parasites inflicted upon the hosts by retardation of growth, emaciation, remarkable decrease in their efficacy as well as decreased production (Nabih and Amal, 2002).

In a number of studies, it has been demonstrated that the cells of hosts infested with different species of parasites, the amount of reactive oxygen radicals increased with the subsequent cell and tissue damage (Sarin et al., 1993). The generation of reactive oxygen species (ROS), 
such as superoxide anion, hydrogen peroxide, hydroxyl radical, and singlet oxygen, in biological systems is dependent on oxygen consumption and can cause cellular damage by lipid peroxidation (Sanchez-Campos et al., 1999). Products of lipid peroxidation formed in various biochemical reactions are normally scavenged by antioxidants. Antioxidants are compounds that are involved in effective scavenging of free radicals and in suppressing the actions of reactive oxygen substances. Antioxidant defences are widely distributed and include both enzymatic and non-enzymatic systems. The major enzymatic antioxidants are superoxide dismutase, glutathione peroxidase and catalase. On the other hand, vitamin $\mathrm{C}$, and vitamin $\mathrm{E}$ are among the non-enzymatic factors that function as antioxidants (Chan, 1993).

Vitamin C (L-ascorbic acid) is a water soluble vitamin that is synthesized in the liver of many species of mammals, including ruminants (Hornig, 1975). Vitamin C status of ruminants is related to their health and disease as it plays an important role as an antioxidant and also has a wide variety of biological function for growth and development of important constituents in the formation of connective tissue (Kanter, 1998 and Medzyavichyus et al., 1989). It has also been suggested to be of value in alleviating both physiological and pathological stress (Jaeschke, 1984 and Hemingway, 1991). In addition, Vitamin $\mathrm{E}$ is another anti-oxidant vitamin that acts as a major peroxyl radical scavenger with powerful chain-breaking properties, and has protective role as a membrane stabilizer is well established (Chan et al., 1999). Reportedly, anti-oxidant vitamins such as E, C, and A protect the cells from damage against free oxygen radicals generated as a result of parasitosis (Tappel, 1968; Medzyavichyus et al., 1989 and Kanter, 1998).

The goal of the present study was to determine the type and burden of parasitic infestation in imported camels and to investigate the effect of enteric parasitism on the oxidative status of affected camels manifested by the changes in the levels of some chain breaking antioxidants.

\section{MATERIALS and METHODS}

\section{Animals}

A total of 29 camels (5-9 years) from an imported herd from Sudan were subjected to clinical and parasitological examination in Shalateen area, Egypt. These animals were free from any clinical signs to diseases except parasitic gastroenteritis. 


\section{Samples and Adopted Methods:}

\section{A- Blood serum samples:}

$10 \mathrm{ml}$ whole blood samples were collected from the jugular vein from all camels under investigation in vacutainer tubes (Containing no anticoagulant) and processed for separation of serum according to Coles (1986). Serum level of vitamin C (L-ascorbic acid) were determined according to Omaye et al. (1979) and vitamin E ( $\alpha$ - tocopherol) according to Martinek (1964) which were measured spectrophotometrically as previously described using digital ultraviolet Spectrophotometer (Digital Ultraviolet Spectrophotometer, CE 292, series 2, Cecil instruments, Cambridge England, Series No. 52.232).

\section{B- Fecal samples}

Rectal fecal samples were collected from all camels in clean plastic bags and subjected to parasitological examination according to Coles (1986). Macroscopical examination was carried out for each fecal sample to detect the presence of gross parasites, blood or mucous, odour and consistency. Microscopical examinations including direct smear, sedimentation and sugar floatation techniques were performed. Fecal egg count was carried on to determine the degree of infestation using McMaster egg counting technique as previously described by Coles (1986).

\section{Statistical analysis}

Statistical analyses were undertaken using one-way ANOVA (the findings were expressed as Mean \pm SD) and by means of statistical Package for the Social Sciences for Windows (SPSS, version 10.0, Chicago, IL, USA),

\section{RESULTS}

\section{Clinical and Parasitological Infestation}

Clinical and parasitological examination of the 29 camels revealed that out of the examined 29 camels, 20 camels were found infested with gastrointestinal nematodes, some of which, showed variable degrees of non-specific clinical manifestation ranged from loss of body weight, paleness of mucous membranes, softness of fecal matter and ill-thriftiness. Three different types of nematodes; Strongyloid, Trichuris and Trichostrongylus species were recovered from 11, 5 and 4 animals, respectively (Fig. 1). Egg counts per gram feces in the infested camels were ranged from 900-2700 EPG. 
The remaining 9 camels were free from gastrointestinal parasites and proved healthy after precise clinical and laboratory examinations and were used as the control group of the study.

\section{Biochemical analysis}

The results showed the presence of significant reduction in the serum level of ascorbic acid in parasitic infested camels as compared to the healthy control group. On the other hand, none of the parasitic infested camels showed significant change in the serum level of vitamin E. (Table 1).

Fig. 1: Different types of nematodes eggs of camel. A) Strongyloides egg containing larva, B) Strongyloides first stage larva,

C) Trichuris species egg and D) Trichostrongylus species egg

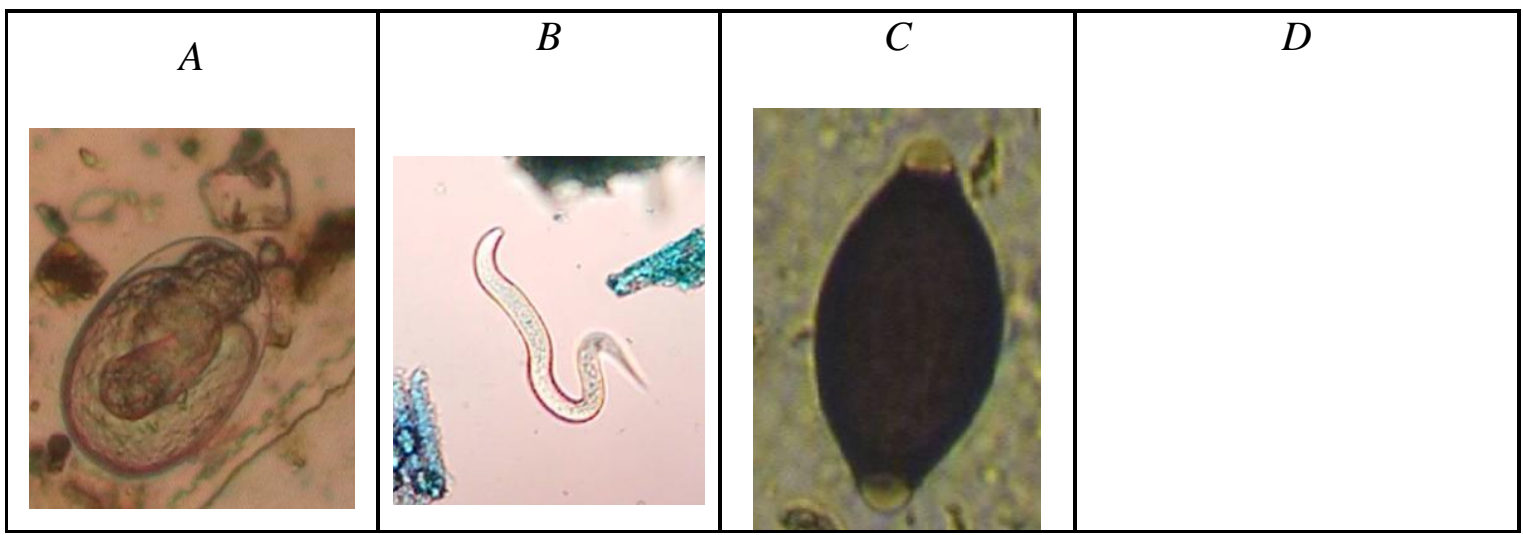

Table 1: Values (Mean \pm SD) of blood serum vitamin $C$ and vitamin $E$ in studied groups of camel.

\begin{tabular}{|c|c|c|}
\hline Camel groups & $\begin{array}{c}\text { Vitamin C } \\
(\mu \mathrm{mol} / \mathrm{l})\end{array}$ & $\begin{array}{c}\text { Vitamin E } \\
(\mu \mathrm{mol} / \mathrm{l})\end{array}$ \\
\hline Control (9) & $32.93 \pm 6.81$ & $12.97 \pm 0.27$ \\
\hline Strongyloid sp. (11) & $13.62 \pm 6.80 * *$ & $14.44 \pm 2.9^{\mathrm{NS}}$ \\
\hline Trichuris sp. (5) & $10.22 \pm 3.12^{* *}$ & $15.91 \pm 2.7^{\mathrm{NS}}$ \\
\hline Trichostrongylus sp. (4) & $12.49 \pm 7.94 * *$ & $13.09 \pm 1.47^{\mathrm{NS}}$ \\
\hline
\end{tabular}




\section{DISCUSSION}

The overall rate of nematode parasitic infestation of the studied camels imported from Sudan was about 69\%, as recorded earlier in Ethiopian camels (Bekele, 2002) and those from Nigeria (Egbe-Nwiyi and Chaudhry, 1994). On the other hand, previous studies have showed lower rate of infestation with nematodes ranged between $23 \%$ to $25 \%$ in Egyptian camels (Abdel-All et al., 1998) and camels from Kuwait (Abd El-Salam and Farah, 1988). The varied infestation rate could be attributed to the different geographical areas related to hygiene and managemental factors as well as the difference in sampling period of the year, duration of the study and number of studied animals.

Internal parasites are known to cause severe gastrointestinal problems. Antioxidant systems comprising vitamins have a cellular protective action against oxidative stress resulting in cell, organ and tissue damage as a result of parasitic invasion (Smith and Bryant, 1989; Mishra, et al., 1994 and Dede, et al., 2000). Das et al. (1994) have proposed that, since parasites damage the cells which synthesize the molecules carrying the anti-oxidative agents, a decrease in the numbers of such cells is natural. Babesia sp. cause oxidative degeneration in erythrocytes while Eimeria sp. causes epithelial lesions. Gastrointestinal worms like Trichostrongylidae spp. cause damages in the cellular lining of gastrointestinal tissue, and pulmonary worms like Protostrongylidae spp. damage the cells of the lung tissue (Aksakal and Özer, 1987; Awadalla, et al., 1993; Das, et al., 1994; Ginsburg and Atamina 1994; Mishra et al., 1994; Dede, et al., 1997 and Dede, et al., 2000).

The present study revealed significant decrease in serum vitamin $\mathrm{C}$ concentration and insignificant changes in serum vitamin $\mathrm{E}$ concentration in camels infested with nematodes. The decrease in vitamin $\mathrm{C}$ level may be attributable to the increased utilization of vitamin $C$ by the tissues and also, to the utilization of vitamin $C$ in regeneration of vitamin $\mathrm{E}$, as vitamin $\mathrm{C}$ has a sparing effect on vitamin $\mathrm{E}$ (Chan, 1993). Vitamin E protects the cells from oxidative damage by being converted into vitamin $\mathrm{E}$ radical and the role of vitamin $\mathrm{C}$ is to regenerate oxidized vitamin $\mathrm{E}$ (Tappel, 1968). It was reported that, parasitic infestations are associated with low ascorbic acid status and that camels with natural parasitic infections have a low status of vitamin C (Mohamed and Beynen, 2002). In conclusion, this study showed that camels imported from Sudan are heavily infested with some nematode 
parasites and that such internal parasites adversely affect the antioxidant status of parasitized camels.

\section{REFERENCES}

Abdel-All, A.A.; Sahlab, A.A.M. and Shehab, M.M. (1998): Studies on the helminth parasites of camel in Suez Canal zone. $8^{\text {th }}$ Scientific Congress, Faculty of Veterinary Medicine, Assiut University, 15-17 November, 361-373.

Abd El-Salam, J.M. and Farah, M.A. (1988): Seasonal variations of gastrointestinal helminths of camel in Kuwait. Vet. Parasitol. 28: 93-102.

Aksakal, M. and Özer, E. (1987): Investigations on hematological values and vitamin $E$ levels of sera before and after treatment with antihelmentic drugs in Akkarman sheep. A. Ü. Vet. Fak. Derg., 34: 72-84.

Awadalla, S.F.; Salem, H.A.H. and Awadalla, S.A. (1993): Effect of Ascaridia galli infestation on body weight, vitamin A and some blood constituents in chicken. Vet. Med. J. Giza, 41: 41-45.

Bekele, T. (2002): Epidemiological studies on gastrointestinal helminths of dromedary (Camelus dromedarius) in semi-arid lands of eastern Ethiopia. Veterinary Parasitology, 105, 139-152.

Chan, A.C. (1993): Partners in defense: Vitamin C and vitamin E. Can. J. Physiol. Pharmacol., 71: 725-731.

Chan, A.C.; Chow, C.K. and Daniel Chiu (1999): Interaction of antioxidants and their implication in genetic anemia. Proceedings of the Society for Experimental Biology and Medicine, 222: 274-282.

Coles, E.H. (1986): Veterinary Clinical Pathology. 4th Ed. Saunders Comp. Philadelphia, London, Toronto.

Das, B.S.; Thurnham, D.I. and Das, D.B. (1994): Plasma alphatocopherol, retinol, and carotenoids in children with Falciparum malaria. Am. J. Clin. Nutr., 64: 94-100.

Dede, S., Bildik, A., Deger, S., Değer, Y. and Yur, F. (1997): Plasma vitamin $C$ and ceruloplasmin levels in the sheep infected with Trichostrongylosis. Acta Paras. Turc., 21: 191-194.

Dede, S.; Dĕger, Y.; De ğer, S. and Alkan, M. (2000): Determination of the status of lipid peroxidation and antioxidants in sheep infected with certain endoparasites (Fasciola sp., Trichostrongylidae sp., Eimeria sp.). Acta Paras. Turc., 24: 190-193. 
Dia, M.L. (2006): Parasites of the camel in Burkina Faso. Trop. Anim. Health Prod., 38: 17-21.

Egbe-Nwiyi, T.N. and Chaudhry, S.U. (1994): Studies on prevalence of camel helminthiasis in arid zone of Borno State of Nigeria. Pakistan Vet. J. 14:20-23.

Ginsburg, H. and Atamina, H. (1994): The redox status of malariainfected erythrocytes: an overview with an emphasis on unresolved problems. Parasite, 18: 5-13.

Hemingway, D.C. (1991): Vitamin C in the prevention of neonatal calf diarrhea. Can. Vet. J. 32: 184.

Hornig, D. (1975): Distribution of ascorbic acid, metabolites and analogues in man and animals. Ann. N.Y. acad. Sci., 258: 103118.

Jaeschke, G. (1984): Influence of ascorbic acid on physical development and performance of race horses. In: Proceedings of the workshop on ascorbic acid in domestic animals. Eds., Wegger, I., F.G., Tagwwerker and J. Moustgaard, p. 153-161. Scandinavian Association for Agricultural Sciences and Royal Danish Agricultural Society, Copenhagen.

Kanter, M. (1998): Free radicals, exercise and antioxidant supplementation. Proc. Nutr. Soc., 57: 9-13.

Martinek, R. (1964): Method for determination of vitamin E (total tocopherol) in serum. Clin. Chem., 10: 1078-1086.

Medzyavichyus, A.K.; Bebravichyus, V.Y.; Drebitskene, G.A.; Mozaiene, E.E.; Medzevicius, A.; Bebravicius, V.; Drebickiene, G. and Mozaliene, E. (1989): Effect of vitamin A and C on immunity to Trichuriasis in piglets under industrial farming conditions. Acta Parasitol. Lit., 23: 115-129.

Mishra, N.C.; Kabilan, L. and Sharma, A. (1994): Oxidative stress and malaria-infected erythrocytes. Ind. J. Malariol., 31: 77-87.

Mohamed, H.E. and Beynen, A.C. (2002): Ascorbic acid contents in blood plasma, erythrocytes, leukocytes and liver in camels (Camelus dromedarius) without or with parasite infections. Int. J. Vitam. Nutr. Res., 72: 369-371.

Nabih, A. and Amal, R. Toos (2002): Biochemical changes in the serum of camels infested with some intestinal parasites. Vet. Med. J. Giza., 50: 343-356.

Omaye, S.; Turnbul, J.D. and Savberlich, H.E. (1979): Ascorbic acid analysis. II. Determination after derivatisation with 2.2 . dinitrophenylhydrazine. Selected methods for determination of 
ascorbic acid in animal cells, tissues and fluids. Methods in Enzymology, 62: 7.

Rutagwende, T. (1985): The control of important camel disease in the integrated project of arid lands study area. Camel disease and productivity in the arid lands of northern Kenya. Integrated Project in Arid Lands (IPAL). Technical Report No. E-7, Germany, pp. 9-70.

Sanchez-Campos S.; Tunon M.J.; Gonzalez P. and Gonzalez-Gallego J. (1999): Oxidative stress and changes in liver antioxidant enzymes induced by experimental dicroceliosis in hamsters. Parasitol. Res., 85: 468-474.

Sarin, K.; Kumar, A.; Prakash A. and Sharma A. (1993): Oxidative stress and antioxidant defence mechanism in Plasmodium vivax malaria before and after chloroquin treatment. J. Malariol., 30: 127-133.

Smith, N.C. and Bryant, C. (1989): Free radical generation during primary infections with Nippostrongylus brasiliensis. Parasit. Immunol., 11: 147-160.

Tappel, A.L. (1968): Will antioxidant nutrients slow aging processes. Geriatrics 23: 97-105. 